\title{
"Metaphor" and "Al-Majaaz" in Translation
}

\author{
Hesham Sayed Abdelnasser
}

\begin{abstract}
:
Metaphor is generally considered as a figure of speech that is formed by language to produce wider implications of understanding. As a result, translators who embark on translating metaphorical texts need to understand the ST comprehensively to extract the embodied meaning. That ectracting requires a deep understanding of metaphors.

The paper surveys and discusses the English definitions of the term "Metaphor", and the Arabic definitions of the term "Al-Majaaz", the functions and the structures of both terms in both languages to find out how different or similar they are, in order to investigate the nature of metaphor and to be able to translate it. Then the study puts the definitions and the structures of metaphor and Al-Majaaz in a comparative diagram to analyze and detect the differences easily.

The primary methodology for this study is literature review and conceptual modeling, with a view to identification and classification in an attempt to reach generalizable conclusions. The study approaches analytically the different definitions, types, functions, and structures of "Metaphor" and "Al-Majaaz", aiming at understanding the deep meaning of such images, not at choosing the best Arabic equivalent to the word 'Metaphor'. As 'Structure' can help understanding a meaning of a certain metaphor or image.

The study has concluded that metaphor and Al-Majaaz have the same function and uses, yet they are structurally different. By realizing the nature of metaphor and detecting the areas of difficulty in the process of translation, translators need to find a suitable theory for understanding, investigating and interpreting metaphorical texts, to explore their deep meanings.
\end{abstract}


Key words: "Metaphor", "Al-Majaaz", "translation", "Esteaara". "Image"

\section{1- Metaphor}

Many studies, which have been conducted on metaphors, have revealed that there is no one finite definition for the term "metaphor", because there are many disciplines in which metaphor is of an interest that is because the topic is truly multi-disciplinary. Philosophies of language, semantics, and other disciplines have studied that term. In linguistics, for example, there is an increasing concern with pragmatics, and an increasing interest in the nature of the text. This resulted in paying more attention to the non-literal uses of language.

In her book entitled Metaphor and religious language, Janet Martin wrote:

One scholar claims to have found 125 different definitions, surely only a small fraction of those which have been put forward, for not only is the subject matter exclusive, but a definition of metaphor useful to one discipline often proves unsatisfactory to another. (Soskice, 1985:15)

Accordingly, it is not extraordinary to find the early analysts investigate metaphor, its structure, how it works, and try to define it. Metaphor has been approached in terms of etymology, structure, function and nature. Janet Martin argues that the term metaphor is derived from a Greek origin:

Amongst Greek grammarians of the classical period "metaphor"(Which literally means 'transfer'); Meta 'trans' + phor 'to carry') was recognized as a means by which language was both ornamented and extended (Soskice, 1985: 1) 
Functionally speaking Soskice considers metaphor as a portrait that is formed by language to produce a further imagination and another horizon of understanding.

The typical definition of metaphor is viewed as;

Metaphor is that figure of speech whereby we speak about one thing in terms, which are seen to be suggestive of another. (Soskice 1985: 1)

The nature of the metaphor was cited in Sir Herbert Read's book English Prose Style:

Metaphor is the synthesis of several units of observation into one commanding image; it is the expression of a complex idea, not by analysis, nor by abstract statement, but by a sudden perception of an objective relation. (1970: 16)

The previous definition is also regarded as a literary critical account of metaphor which claims that metaphor is a process of imagination, or a sort of emotive response. Soskice (1985:.20) cites another confirmation under the title, "The structure of metaphor", which deals with the difficulty of determining a confined basis for identifying the essential nature and structure of "metaphor". She quotes Ullmann's argument:

The basic structure of metaphor is very simple", says

Ullmann. He adds: "There are always two terms present: the thing we are talking about and that to which we are comparing it

Despite what Soskice has mentioned regarding the difficulty of determining a basis upon which the structure of metaphor could be based, the study regards the previous definition as one that points out the structure of metaphor. 
The two components of the metaphor were described by I.A Richards, in his book entitled The Philosophy of Rhetoric (1936:130) as follows:

A metaphor consists of two parts: the tenor and vehicle. The tenor is the subject to which attributes are ascribed. The vehicle is the subject from which the attributes are borrowed.

The following example will explain the previous quotation:

Life is a flight,

And all people merely passengers

They have their exits and their entrances.

In this example, "the life" is compared to a flight, the aim being to describe the life by taking well-known attributes from the flight. In this case, the life is the tenor and the flight is the vehicle. "People" are a secondary tenor and "passengers" is the vehicle for this secondary tenor.

\section{1- Types of metaphor}

There are several types of metaphor in English language. The study tackles them as follow:

- An extended metaphor, or conceit, sets up a principal tenor with several subsidiary vehicles or comparisons. The above example is a suitable one. The life is described as a flight and then people are subsidiary subjects that are further described in the same context.

- An epic or (Homeric Simile) is considered as an extended metaphor containing more details about the vehicle that are not, in fact, necessary for the metaphoric purpose. for example: 
This is a crisis. A large crisis. In fact, if you've got a moment, it's a twelve-storey crisis with a magnificent entrance hall, carpeting throughout, 24-hour porter age and an enormous sign on the roof saying 'This Is a Large Crisis. (Black Adder)

- A mixed metaphor is one that leaps, in the course of a figure, to a second identification that is inconsistent with the first one. Example: "He stepped up to the plate and grabbed the bull by the horns," where two commonly used metaphors are confused to create a nonsensical image.

- A dead metaphor is one in which the reader can't observe a sense of a transferred image. Example: "to grasp a concept" or "to gather what you have understood." Both of these phrases use a physical action as a metaphor for understanding (itself a metaphor), but in none of these cases do most speakers of English actually visualize the physical action.

- Extended metaphor is the core of many widespread types such as Epics.

Another point is taken out of that survey that is the English types of metaphor are not classified structurally but according to how they function, are they observed or not? and are they commonly being used or not?

It is worth noting that the difficulty of metaphor is finding out the relations between word and sentence meaning on the one hand, and the speaker's meaning or utterance meaning on the other hand. Many writers refer to the fact that there are two kinds of sentence meaning, namely, literal and metaphorical.

Sentences and words appear to have only their surface meanings, however, when we talk about the metaphorical meaning of a word, an expression or a sentence, we are talking about what a speaker might mean when uttering in a way that departs from what the word, expression, or sentence superficially means. 
The study requires introducing a "working definition", a definition that is chosen for an occasion and may not fully conform with established or authoritative definitions. Not knowing of established definitions would be grounds for selecting or devising a working definition.

The study adopts Caroline Spurgeon's definition in her book Shakespeare's Imagery and What It Tells Us. Caroline Frances Eleanor Spurgeon was an English literary critic.

In 1935, Spurgeon wrote the pioneer study on the use of images in William Shakespeare's Work, called Shakespeare's Imagery, and what it tells us. It has been reprinted several times. In it she analyses the different types of images and motifs that he uses in his plays.

The study of imagery can, apart from helping to understand the meaning of the play, give some insight into the poet's mind, because it shows what ideas come to his mind when in need of poetic expression, thus giving some clues as to his background, his upbringing, his social position, and so on.

Dr Mohamed Enany in his book Kadaya Al-Adab Al- Hadeath (1995:49) devotes a specific chapter to survey Caroline's book, he cites:

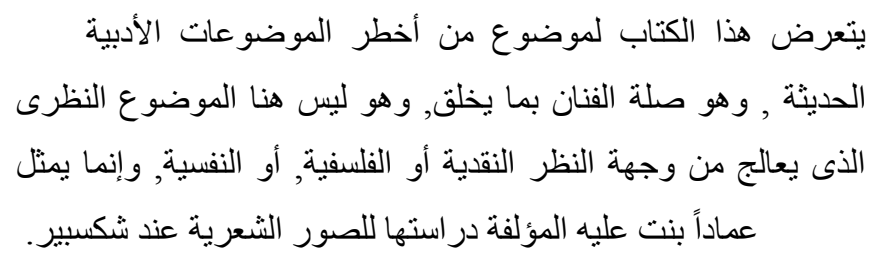

This book tackles one of the most important modern literary issues, which is the relation between the artist and his products. Here, it is not just a theoretical subject which is dealt with critically, philosophically, nor psychologically, but it forms a basis upon which 
the author has built her study of Shakespeare's imagery.

Caroline discards the delicate distinctions between similes and metaphors, specially the structural distinctions. She pays more attention to the common factor of them which is the imagery.

Dr Mohamed Enany discusses Spurgeon's view and quotes her definition to make it clear, he says:

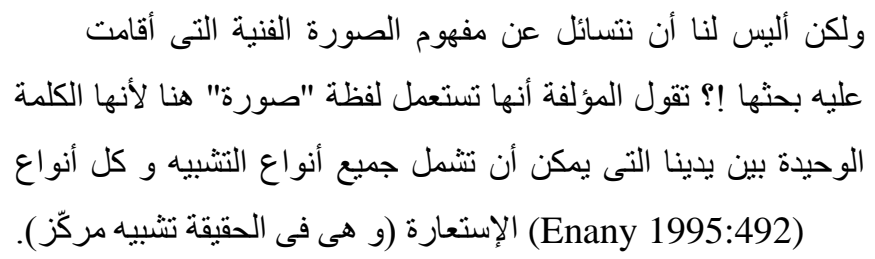

Spurgeon argues:

I use the term 'image' here as the only available word to cover every kind of simile, as well as every kind of what is really compressed simile-metaphor. (Spurgeon, 1968:5)

She describes metaphor -the compressed simile- as an "image". It is not the common visual image, but it connotes any and every imaginative picture may have come to the poet.

I suggest that we divest our minds of the hint the term carries with it of visual image only, and think of it, for the present purpose, as connoting any and every imaginative picture or other experience, drawn in every kind of way which may have come to the poet, not only through any of his senses, but through his mind and emotions as well, and which he uses, in the forms 
of simile and metaphor in their widest sense, for the purpose of analogy.

Caroline argues that metaphor or 'image' involves the secret of the universe. She says:
"Likeness between dissimilar things holds within itself the very secret of the universe. The bare fact that germinating seeds of falling leaves are actually another expression of the processes we see at work in human life and death, thrills me, as it must others, with a sense of being here in presence of a great mystery, which, could we only understand it, would explain life and death itself. "(Spurgeon, 1968:6)

An example for this concept of metaphor i.e. "image" can be found in Paradise Lost by Milton. Enany mentions in the introduction of his translation of Jon Milton's Paradise Lost:

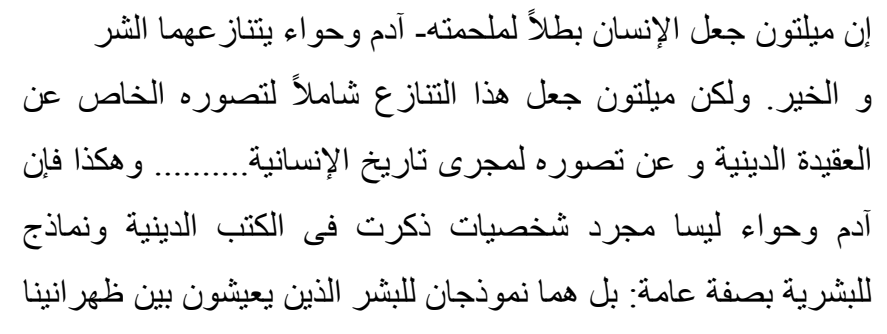

. ( Enany.2002:57)

Milton makes human as a hero of his epic- Adam and Eve are disputed by Good and Evil. Milton makes this disputation included his private concept about the religious creed and about human history........ As such, Adam and Eve are not mere characters who are mentioned in the holy books or prototypes for human 
in general: but they are samples of people who are living between us.

An example where Milton describes Adam and Eve's expulsion out of Paradise makes it clear:

645. Som natural tears they drop'd, but wip'd them soon;

646. The World was all before them, where to choose

647. Thir place of rest, and Providence thir guide:

648. They hand in hand with wandring steps and slow,

649. Through Eden took thir solitarie way. (paradiselost.org. 2011)

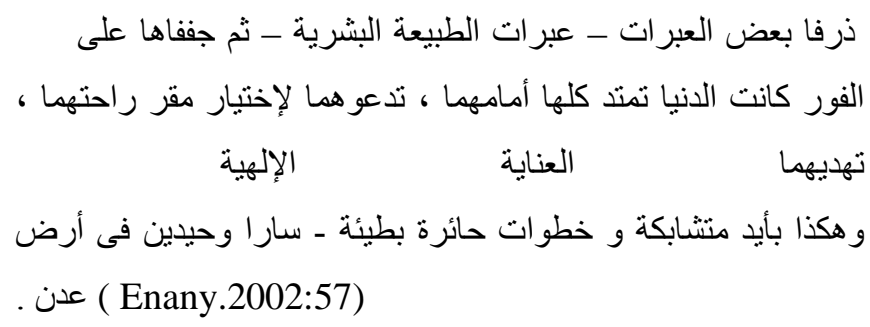

Enanny has confirmed Milton's continuous awareness of real life in his age because the lyric-superficially- is far from the human day life. It doesn't contain even one human character and the location where actions took place is totally strange, Milton intended to make it different from what human knows on Earth. However, Milton managed to grant the human style to his conception about Hell and blindness.

In terms of dealing with images, the study presents the classifications of images which fall into universal, private and cultural. 
UNIVERSALS: Qualities of literature that appeal to readers in a wide variety of cultures and across a wide variety of historical periods--i.e., basic emotions, situations, values, and attitudes that readers can relate to regardless of other cultural or historical differences. Universal symbol is another term for an archetype. (Literary Terms and Definitions, 2011)

ARCHETYPE: An original model or pattern from which other later copies are made, especially a character, an action, or situation that seems to represent common patterns of human life. Often, archetypes include a symbol, a theme, a setting, or a character that some critics think have a common meaning in an entire culture, or even the entire human race. These images have particular emotional resonance and power. Archetypes recur in different times and places in myth, literature, folklore, fairy tales, dreams, artwork, and religious rituals. Archetypes are also called universal symbols. Contrast with private symbol.

CULTURAL SYMBOL: A symbol widely or generally accepted as meaning something specific within an entire culture or social group, as opposed to a contextual symbol created by a single author that has meaning only within a single work or group of works. Examples of cultural symbols in Western culture include the cross as a symbol of Christianity, the American flag as a symbol of America's colonial history of thirteen colonies growing into fifty states, the gold ring as a symbol of marital commitment, the Caduceus as a symbol of medicine, and the color black as a symbol of mourning. Examples of cultural symbols in other cultures include white as a symbol of mourning in Japan, the Yin-Yang sphere as an oriental symbol of oppositional forces in balance, the white crane as a symbol of longevity in Mandarin China, and so forth.

Any writer in a specific culture could use one of these symbols and be relatively confident that the reader would understand what each symbol represented. Thus, if a writer depicted a pedophilic priest as trampling a crucifix into the mud, it is likely the reader would understand this action represents the way the priest tramples Christian ideals, and so forth. (Literary Terms and Definitions, 2011) 
Cultural Images are drawn from the poet's own culture which may mean very little if translated as they are into the terms of another culture.

PRIVATE SYMBOL: In contrast with an archetype (universal symbol), a private symbol is one that an individual artist arbitrarily assigns a personal meaning to.

Nearly all members of an ethnic, religious, or linguistic group might share a cultural symbol and agree upon its meaning with little discussion, but private symbols may only be discernable in the context of one specific story or poem. (Literary Terms and Definitions, 2011)

Private symbols are images invited by the author for the first time and only for a specific situation. Examples of private symbols include the pilgrim scene on the first meeting between Romeo and his lover Juliet, created by William Shakespeare in Romeo and Juliet. In Act one, Scene five, Romeo utters the following extract;

\section{ROMEO}

(Taking Juliet's hand) If I profane with my unworthiest hand

This holy shrine, the gentle sin is this:

My lips, two blushing pilgrims, ready stand

To smooth that rough touch with a tender kiss.

JULIET

Good pilgrim, you do wrong your hand too much, Which mannerly devotion shows in this;

For saints have hands that pilgrims' hands do touch, And palm to palm is holy palmers' kiss.

ROMEO

Have not saints lips, and holy palmers too?

JULIET

Ay, pilgrim, lips that they must use in prayer.

ROMEO

then, dear saint, let lips do what hands do:

They pray: 'Grant thou ,lest faith turn to despair'.

JULIET

Saints do not move, though grant for prayers' sake. 


\section{ROMEO}

Then move not, while my prayer's effect I take.

Thus from my lips, by thine, my sin is purged.

\section{JULIET}

He kisses her

Then have my lips the sin that they have took.

\section{ROMEO}

Sin from my lips? 0 trespass sweetly urged!
Give me my sin again.
He kisses her

1991: 55)

JULIET You kiss by the book. (Shakespeare.

Romeo is found to be a lively, intelligent and popular youth who has been moody, depressed and solitary by his infatuation with Rosaline. He leads the life of the dandy with his friends and has experience of strong affection outside his family in the form of his infatuation for Rosaline. Whereas Juliet, younger than Romeo, not yet fourteen and still very much obedient to the authority of her parents. She has, at the beginning of the play in particular, the reserve of a young girl who is not used to the world outside her family home.

Juliet is at the prime of her beauty as she is going to meet a young man of her family who wants to marry her. Romeo sees Juliet in this scene as he attends this party in disguise dressed as a pilgrim. In this situation Romeo has to put in mind that he is in the house of the opponents of his family. Romeo is speaking to a beautiful highborn virgin and this requires a delicate style. This background helps understand the motives behind Romeo's choice of words by which he creates a unique private metaphorical image that implies holy religious connotations.

\section{- Al-Majaaz:}

The term "Al Magaaz" in the Arabic lexicon is defined as:

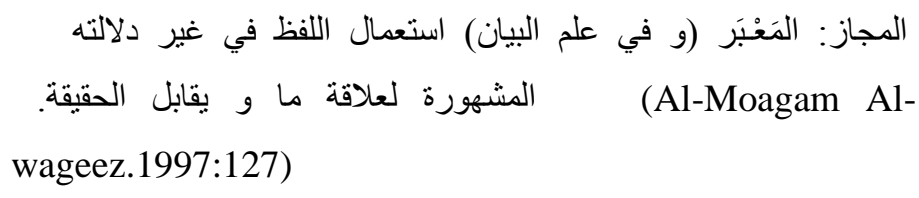


Al-Majaaz: The passage, (in rhetoric usage) using the uncommon denotation of the utterance for a relation to compare it with reality.

Al- Dokhmaisy says that:

$$
\begin{aligned}
\text { المجاز هو : اللفظ الجائز من شيء إلى شيء تشبيهاً بالجسم المنتقل من موضع إلى آخر. (Al- Dokhmaisy, 2002:12) }
\end{aligned}
$$

Al-Majaze" means the passing utterance from a thing to another the same as the moving body from a place to another.

Many Arab writers have discussed this term and its different uses, such as Ibn-Manzour's account in "Lesaan Al-Arab":

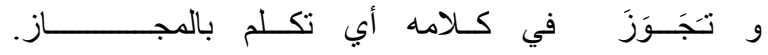

(Ibid:11)

"Tajawaza" He used metaphor in his speech, means, "He spoke metaphorically".

Another considerable definition has been given by Al Jarjany:

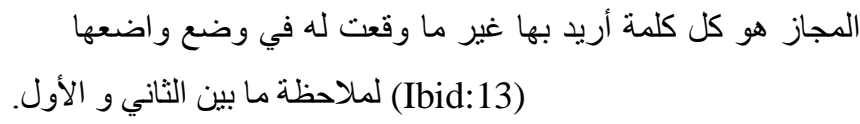

Al Majaaz ;"Metaphor" means; any word used to refer to what is unlike its common usage to observe the distinction between the former and the and the later.

As for the structure of Al-MAjaaz, there are some famous accounts, such as that of $\mathrm{Al}$ Hashemi in his book Jawaher Al 


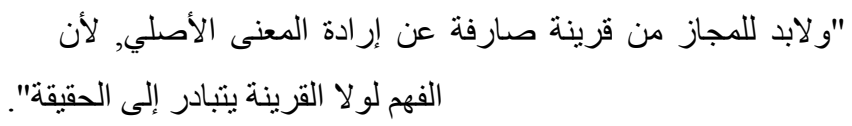

Al-majaaz must have an evidence distracting from aiming at the surface meaning as but for evidence, comprehension seeks to the reality.

Al Hashemi argues that the evidence is a fundamental condition for forming metaphor. By the evidence he means: the logical reason that prevents the reader from expecting that what the writer intends is the truth. Al-Zrkashy tries to give a clearer illustration of this point .He says:

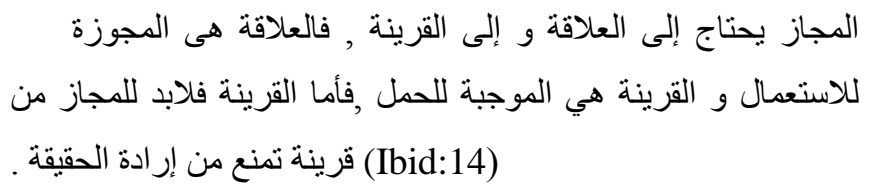

Al- Magaaz requires a "relation" and an "evidence" .The relation legitimates the usage. And it is the evidence which necessitates the readers to adopt the metaphorical meaning. The metaphor must have an evidence that prevents from aiming at the truth.

Al-Samarkandy addresses the truth and Al Majaaz in terms of the nature of each of them.

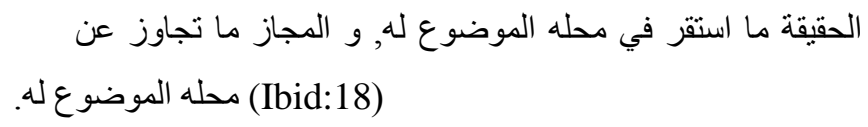

The truth is what fits the utterance and "Al Majaaz" is what passes the utterance.

Al-Saafy Al-Hendy defines Al Majaaz as:

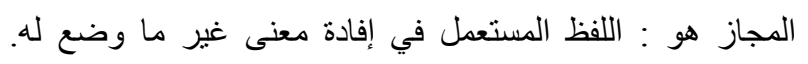

(Ibid:15) 
Using an utterance to give a meaning that differs

from what it has meant to be.

\section{The following classification of rhetoric in Arabic clarifies that easily:}

The classification of Arabic rhetoric تصنيف علم البيان

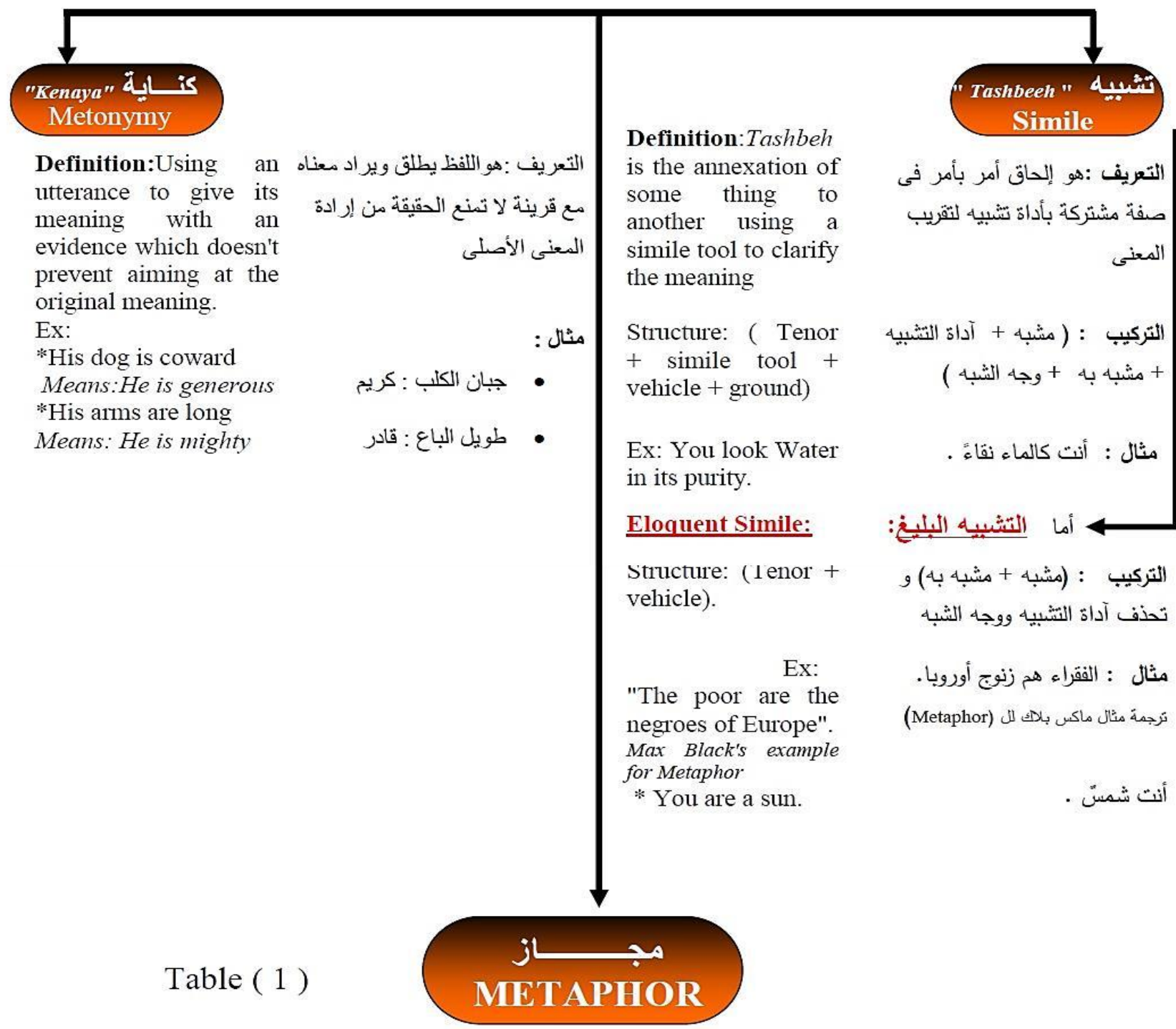

Al-Majaaz: The passage, (in rhetoric usage) using the uncommon denotation of the utterance for a certain relation with an evidence that prevents from aiming at the truth.

$$
\begin{aligned}
& \text { المجاز : هو المعبر( و فى علم البيان ) }
\end{aligned}
$$

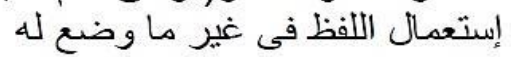

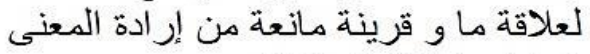

$$
\begin{aligned}
& \text { الحقيقى (يقابل الحقيقة) }
\end{aligned}
$$




\section{Types of " Majaaz" أنواع المجاز}

MajazAkli مجاز عقلى

Mental Metaphor

It is the metaphor in

which the mind and the impossibility prevent the reality.

Ex: The general has defeated the army.

It is impossible for the leader to defeat an army by himself only.

\section{* The council decided} so and so ...

It is not the council which decides but its members.

* He lives a satisfied life.

The life doesn't satisfy, but the person who lives it can be satisfied.

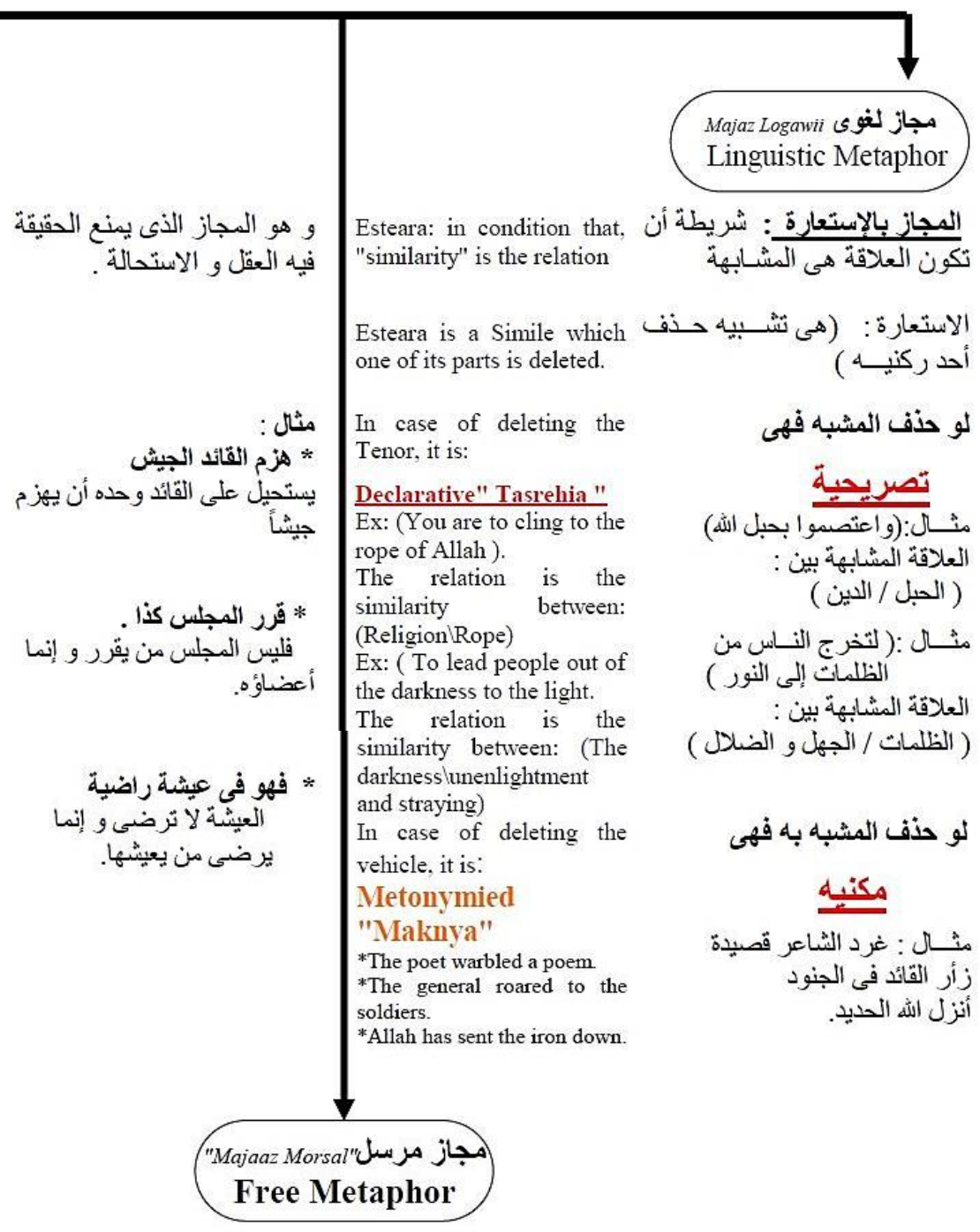

\section{When the relation is not the "similarity", Metaphor يسمى المجاز مرسلا إذا لم تكن العلاقة المشابهة}

\section{is called Free Metaphor.}

Ex:The cattle grazed the rain. ( causational relation).

The rain causes the grass.

* Releasing a believer neck. (partial relation).

The neck is a part of the believer.

* They say by their mouths. (totality relation). It means by their tongues.
مثال :* رعت الماشية الغيث (علاقة السببسة) الغيث بيبب النبات الغياته

* تحرير رقبة مؤمن. علاقة الجزئية ) الرقبة جزء من المؤمن مؤن

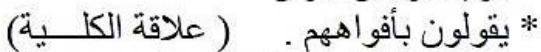
و المعنى الأصلي بألسنته 
Arabic Rhetoric includes three rhetoric types that are " Tashbeeh " تثبيه Simile,

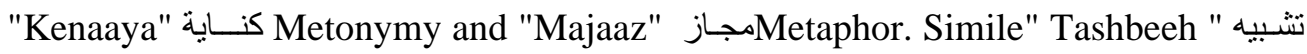
contains another subsidiary type which is Eloquent Simile.

The term "Majaaz" includes three different types, they are; Majaz Loghawi مجاز لغوى Linguistic Metaphor, Majaaz Akli مجاز عقلى Mental Metaphor, and "Maajaz Morsal"مجاز مرسل" Free Metaphor.

\section{Conclusion}

Having investigated both $\mathrm{Al}$ Majaaz and metaphor in the sense that a comprehensive comparison has been made to compare their different aspects, it has been concluded that they have the same function and uses, yet they are structurally different.

The study has analyzed metaphor and Al-MAjaaz, their definitions, types, and structures in order to detect the areas of difficulty in the process of translating images. Accordingly, it has been recommended by the study's findings that translators should analyze metaphorical texts hermeneutically in order to accomplish an adequate translation.

\section{References}

Bell, R. (1991). 'Translation and Translating; Theory and Practice'. London and New York: Longman.

Enany, M. (1996) 'Comparative Moments '.Cairo( with M.S .Farid). Egyptian Bookshop.

Enany, M. (1995) 'The Comparayive Tone'. Cairo.(with M.S. Farid). 
Gentzeler, E. (1993) 'Contemporary Translation Theories', London and New York : Routledge.

Herbert Read, (1970) 'English prose style' Boston: Beacon Press

Holmes, J.S.(ed.) (1970) 'The nature of Translation: Essays on the Theory and Practice of Literary Translation'. The Hague and Paris: Mouton

I A Richards; C S Lewis (1936) 'The philosophy of rhetoric', New York ; London : Oxford University Press.

James, C. (1980)'Cotrastive Analysis'. London : Longman.

Koller, W. (1989) 'Equivalence in Translation Theory', Translated from the German by A .Chesterman,in A. Chesterman.

Leech, Geoffery(1974) 'Semantics ' Penguin Books.

Newmark, P. (1982) 'Approaches to Translation', Oxford and New York: Bergman.

Nida, E.A, C.wR. Taber, (1985) 'The Theory and Practice of Translation', U.B.C,.

Ortony, Andrew ed. (1979) 'Metaphor and thought, (Cambridge; Cambridge University Press),

Palmer, F.R. (1981) 'Semantics', (Cambridge: Cambridge University Press)

Simpson, Paul. (1981) 'Language through Literature', (London: Routledge).

Soskice, Janet Martin, (1985) 'Metaphor and Religious language' (Oxford; Clarendon press),

Spurgeon, Caroline F. E. 'Shakespeare's Imagery and What It Tells Us', Cambridge.

Venuti, L. (1995) 'The Translator's Invisibility; A History of translation .London and New York: Routledge. 


\section{Arabic References}

الثعالبى(2003): فقه اللغةو أسرار العربية.القاهرة :مطابع بن سيناء.

أحمد صبرة :التفكير الإستعارى فى الدراسات الغربية. القاهرة :دار الصديقان للنشر.

السيوطى (2004) : المز هر فى علوم اللغة و أنو اعها ـ بيروت : المكتبة العصرية.

عبدالرحمن بن خلدون (2004) : مقدمة بن خلدون . القاهرة :دار الفجر للتراث.

عبدالعظيم المطعنى (2004) : المجاز فى اللغة و القرآن الكريم ـ القاهرة :مكتبة و هبة.

محمد عنانى : (1995): قضايا الادب الحديث. القاهرة : الهيئة المصرية العامة للكتاب-. 